\title{
Exploring Israeli Venture Capital Investing In Renewable Energy
}

\author{
David A. Blum, Northcentral University, USA
}

\begin{abstract}
Israel's venture capital market is one of the largest in terms of capital investing in the world. However, in 2014, 5 of 83 independent venture capital firms located in Israel invested in renewable energy portfolio companies. The result of investing in few renewable energy firms in Israel is a continued reliance on imported fossil fuels from geographically distant nations. The importation of fossil fuels creates an added security risk in an already hostile political environment. The gap in research addressed in this paper explored factors for the small number of renewable energy firms receiving venture capital funding in Israel. The research question guiding this study was what are the factors for the small number of renewable energy firms receiving funding in Israel. The lack of renewable energy firm funding appears to be as a result of three factors. First is low return on investment. Second is regulatory uncertainty from the Israeli government. Third is the lack of knowledge of renewable energy by independent venture capitalists.
\end{abstract}

Keywords: Independent Venture Capital; Israel; Renewable Energy

\section{INTRODUCTION}

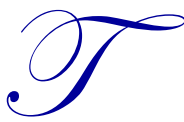

he State of Israel is a geographically small nation about the size of the U. S. state of New Jersey surrounded by enemy populations (CIA World Factbook, 2014). Although situated in a hostile environment, the nation has endeavored to become the world leader in technological innovation and entrepreneurship (Invest in Israel, 2014). The Israeli government invests approximately $4.38 \%$ of gross domestic product in research and development (R\&D) (Invest in Israel, 2014). Although government funds are allocated for agricultural, water resources, and technological R \&D advancements, the nation is entirely reliant on coal, and petroleum imports to power the economy (Invest in Israel, 2014; OECD, 2011). To reduce the nation's dependence on imported energy and enhance national security, the government has promoted energy efficiency and the use alternative energy sources such as solar and wind (Invest in Israel, 2014). As a result, the production of renewable energy, primarily solar, is the most advanced of Organisation for Economic Co-operation and Development (OECD) countries (OECD, 2011). However, in 2013 solar supplied $0.38 \%$ of the total electricity consumption while all renewable energy sources accounted for $0.87 \%$ of energy produced (Ministry of Environmental Protection, 2014).

Israel's venture capital market is one of the largest in the world (Levenfeld, Platt, Romem, \& Arnon, 2009). However, in 2014, 6\% of independent venture capital (IVC) firms located in Israel invested in renewable energy companies (Israel Science and Technology, 2014). Low numbers of IVC participation in renewable energy portfolio companies might be a result of three factors, which are explored in this paper. IVCs in Israel fund (a) Internet and ecommerce, (b) biotech, (c) medical devices, (d) communications, (e) semiconductor design and manufacture, and (f) enterprise software firms (Israel Science and Technology, 2014; Levenfeld et al., 2009).

Scant reasons exist in the extant literature addressing the underexplored phenomenon of why few Israeli IVCs invest in renewable energy firms. To address the phenomenon, I conducted a qualitative multiple case study in October and November 2014 interviewing 15 IVC partners and directors in the Israel. The research question guiding the study was what are the factors for the small number of renewable energy firms receiving funding in Israel. This paper provides (a) an overview of the State of Israel, (b) Israeli energy policy, (c) renewable energy, (d) Israeli 
renewable energy policy, (f) renewable energy use in Israel, and (e) Israeli venture capital. I outlined the study parameters and presented factors contributing to low levels of funding renewable energy firms.

\section{LITERATURE REVIEW}

\section{Facts About Israel}

The State of Israel declared independence on May 14, 1948 (Ministry of Foreign Affairs, 2013a). On June 1, 2014 the State of Israel population was estimated at 8.2 million (Central Bureau of Statistics, 2014). Approximately $75.2 \%$ of the population is Jewish (Central Bureau of Statistics, 2014). The Arab population including Christians, Muslims, and Druze account for approximately $20.6 \%$ of the population. The remaining $4.2 \%$ is non Arab Christians, persons with no religious affiliations, or those who practice a religion other than Judaism, Christianity, or Islam (Central Bureau of Statistics, 2014). The geographical area of the State of Israel is 8,630 sq. miles / 22,145 sq. kilometers (Israel Ministry of Foreign Affairs, 2013b). Israel's GDP-purchasing power parity was estimated in 2013 to be $\$ 273.2$ billion (CIA World Factbook, 2014). The GDP per capital was estimated to be $\$ 36,200$ in 2013 (CIA World Factbook, 2014).

Israel is ranked number one in the world for innovation and first in entrepreneurship (Invest in Israel, 2014). Israel is noted for having a thriving entrepreneurial spirit (Invest in Israel, 2014). For example, in proportion to the nation's population, Israel has the largest number of startup companies in the world (Israel 21c, 2013). Israel is first in the number of technicians and scientists working in industry (Israel 21c, 2013). Israel ranks number one in the number individuals employed in technical professionals (Israel 21c, 2013). The nation was the only country to enter the 21st century with a net gain in the number of trees (Israel 21c, 2013).

In 2014, 75 Israeli companies out of approximately 2,955 were listed on NASDAQ, more than from Europe, all Muslim dominated nations, Japan, South Korea, India, and China combined (Nasdaq, 2014a; Nasdaq, 2014b). One reason could be Israel leads the world in research collaboration between industry, academia, and government (Invest in Israel, 2014). Israel's research collaboration creates an environment for scientific innovation resulting into marketable products and profitable ventures (Invest in Israel, 2014). The collaboration is one explanation how Israel as a small geographically and population sized nation regionally and politically isolated reaches $\$ 25$ billion per year in technological exports (Invest in Israel, 2014).

Israel invests $4.38 \%$ of GDP into R\&D, which leads the world (Invest in Israel, 2014). The government through the Office of the Chief Scientist of the Ministry of Economy and via a network of technologically diverse incubators as well as an active venture capital market provides extensive support for new ideas and technologies (Invest in Israel, 2014). Israel is second to Silicon Valley California in the highest concentration of high-tech companies (Invest in Israel, 2014).

Israel's venture capital market is highly developed estimated to be $\$ 1$ billion (Invest in Israel, 2014). The World Economic Forum Global Competitiveness Yearbook for 2014-2015 ranked Israel 9th for venture capital availability out of 148 economies (Invest in Israel, 2014). Figure 1 is a map of the State of Israel with the four largest populated cities noted. 
Figure 1. Map of the State of Israel

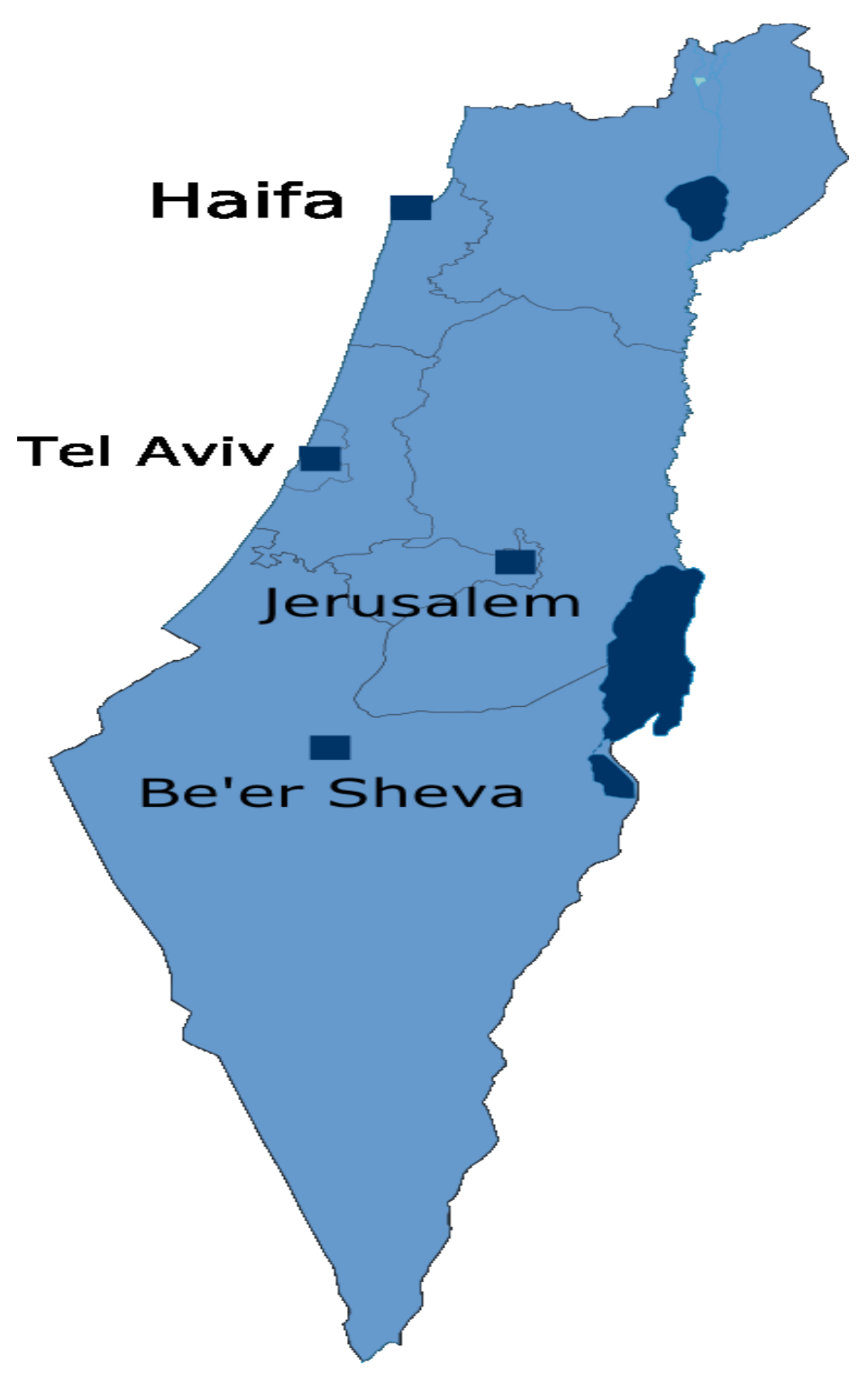

\section{Israel Energy Policy}

For all of Israel's economic success, the country is dependent almost entirely on imported coal and oil to power the country (OECD, 2011). Except for oil supplies from Iran (mid-1950s to 1979) and Egypt, Israel has been reliant on geographically distant nations such as Mexico, Norway, and Nigeria (Escribano, 2008). As a result of the fall of the Soviet Union, Israel has been able to purchase oil from Russia, Azerbaijan, Kazakhstan, and Turkmenistan (Escribano, 2008). Israel imports approximately 80\% crude oil from Russia and Azerbaijan by tanker vessels (EIA, 2013). Israel is reliant on imports because scientists have not been able to locate sufficient fossil fuels under the country's territory (Escribano, 2008). Because of poor or nonexistent relations with neighboring countries, Israel does not participate in international oil pipelines or electricity connections (EIA, 2013; Escribano, 2008). Israel does have a link is to the East Mediterranean Gas pipeline terminating at the southern Israeli port city of Ashkelon (Escribano, 2008). 
Israel has managed to reduce both its energy dependence and economic vulnerability. The promotion of energy efficiency and alternative renewable energy sources is vital for the energy security of the country. Israel is among the most advanced nations of OECD countries regarding renewable energy R\&D development (OECD, 2011). For Israel, energy security is the main objective of the nation's energy policy because of the geopolitical and religious conflict with neighboring and regional Arab and predominate Muslim nations (Escribano, 2008). The production of renewable energy might be the significant factor toward lessening Israel's reliance on imported energy (Escribano, 2008).

\section{Renewable Energy}

Renewable energy is derived from fuel sources that are restorable over short periods and do not diminish (EPA, 2014). Examples include wind, the sun, water (hydro), biomass, and geothermal. Renewable energy is a potential solution to alleviate the effect of potential human contribution to global warming and in reducing ecological footprints (Sjöö, 2008).

The worldwide use of renewable energy is miniscule in comparison to fossil fuels such as petroleum and coal. Coal is the main fuel source of power generation accounting for $40.9 \%$ of total power output globally (U.S. Department of Energy, 2012). Twenty three percent of all electricity generated worldwide is derived from renewable sources with wind and solar energy the fastest growing renewable electricity technologies (Aguirre \& Ibikunle, 2014).

Neither business organizations nor the market have internalized negative externalities of fossil fuels into the prices for goods and services. Two common emission restriction schemes to account for negative externalities are carbon tax and cap and trade. Cap and trade is a market-based scheme to control greenhouse gas emissions whereby the government restricts the level of pollutants and sets a predetermined cap on emissions an organization can emit over a specified period called a permit (He, Wang, \& Wang, 2012). Carbon tax is a government policy that assesses a tax on businesses emitting carbon dioxide and other fossil fuel pollutants (He et al., 2012). Carley (2009) and Aguirre and Ibikunle (2014) argued emission restriction schemes help renewable energy firms become cost competitive with traditional energy sources.

\section{Israel Renewable Energy Policy}

Israel invests $\$ 1.1$ billion annually in renewable energy projects particularly solar energy (Bahgat, 2005; Bloomberg, 2014; Karakosta, Doukas, \& Psarras, 2010). The nation has the highest per capita solar water heaters use in the world, and is well positioned in classical photovoltaic and thermo-solar technologies (Escribano, 2008). Israel is an acknowledged leader in solar energy since the 1950s (Bahgat, 2005; Karakosta, Doukas, \& Psarras, 2010).

In 2009 the Israeli government decided to increase renewable energy use by $10 \%$ by 2020 (Ministry of National Infrastructures, Energy, \& Water Resources, 2014). The Kyoto Protocol is the primary Israeli regulation and compliance policy (Karakosta et al., 2010). In February 2001, the government set greenhouse gas emission targets and funding mechanisms in accordance to the nation's Kyoto obligations as a signatory (Karakosta et al., 2010). Israel ratified the Kyoto Protocol in February 2004 (Karakosta et al., 2010). Israel was classified as a nonAnnex 1 country (Karakosta et al., 2010).

\section{Renewable Energy in Israel}

Israel is a leader in developing renewable energy technologies (Bloomberg, 2014). Photovoltaic and solar are the main types of renewable energy used in Israel (Ministry of National Infrastructures, Energy, \& Water Resources, 2014). The absorption of photovoltaic solar energy is by panels, which focuses the solar radiation using optical devices usually parabolic mirrors (Ministry of National Infrastructures, Energy, \& Water Resources, 2014). The heat created produces steam propelling a turbine spinning a generator creating electrical energy. 
Construction of two thermal solar power stations in Ashalim in the Negev Desert is under development (Ministry of National Infrastructures, Energy, \& Water Resources, 2014). The power tower facility is expected to supply 250 megawatts of electricity and also a photovoltaic power station with a capacity of 30 megawatts (Ministry of National Infrastructures, Energy, \& Water Resources, 2014). The Ashalim project has a completion date of 2017 (NREL, 2014).

Regarding solar energy, Israel has an abundant amount of sunshine offering significant potential as an energy source (Ministry of National Infrastructures, Energy, \& Water Resources, 2014). The creation of solar energy is by absorbing electromagnetic rays from the sun and converting the rays into electrical energy or thermal energy (Ahituv, 2012). Israel was one of the first countries to adopt solar technologies (Ministry of Economy, 2014). The nation is pioneering the use of electric cars as well as others fields (Ministry of Economy, 2014). Solar is the most advanced renewable energy in Israel, but supplies 197 megawatts to the network grid, or $0.38 \%$ of total electricity consumption (Ahituv, 2012).

Biomass and wind are two other forms of renewable energy used in Israel. Biomass derived from solid waste, landfills, and wastewater is not highly developed, because no efficient waste separation method exists and therefore no regular infusion of organic matter. Biomass contributes about $0.055 \%$ of total electricity used (Ahituv, 2012; Ministry of National Infrastructures, Energy, \& Water Resources, 2014). Wind energy is derived from converting the kinetic energy of the wind into electricity (Ahituv, 2012). Because of geographic, topographic, and environmental reasons, little potential exists in Israel for the wide scale use of wind energy (Ahituv, 2012; Ministry of National Infrastructures, Energy, \& Water Resources, 2014). Wind energy production primarily from the annexed Golan Heights is approximately six megawatts or $0.001 \%$ of total electricity used (Ahituv, 2012).

In 2013 Israel's total installed renewable capacity was about 13,000 megawatts (Ministry of Environmental Protection, 2014). Renewable energy accounted for $0.87 \%$ of energy produced (Ministry of Environmental Protection, 2014). By the end of 2014, the Ministry of Environmental Protection (2014) projects renewable energy sources to generate $2.24 \%$ of Israel's electricity needs.

\section{Israeli Venture Capital}

The Israeli venture capital market is one of the largest in the world (Levenfeld et al., 2009). In 2013, Israeli IVCs invested in $\$ 1.7$ billion representing 3.5\% of global activity (Pearce, 2014). In 2013, Israel ranked fifth behind the United States, Europe, China, and India in invested capital (Pearce, 2014). The government by leveraging financing via foreign corporations and institutions was instrumental in building the Israeli venture capital industry (Baygan, 2003). The government has been active in financing public and private venture capital funds to leverage private capital from foreign investors (Baygan, 2003).

IVCs in Israel invest primarily in seed and early stage companies (Levenfeld et al., 2009). Portfolio companies are normally registered in Israel or as corporations registered in Delaware with Israeli subsidiaries (Levenfeld et al., 2009). Venture capital is the largest segment of private risk investment in Israel (Levenfeld et al., 2009). Venture capital in Israel is very similar to U.S. venture capital as practiced in Silicon Valley or Boston, with similar deal terms and documents (Levenfeld et al., 2009).

Researchers have emphasized the positive impact of IVCs on the growth and strength of high-tech companies (Avnimelech, Schwartz, \& Bar-El, 2007; Florida \& Kenney, 1988; Gompers \& Lerner, 1999, Gompers \& Lerner 2001; Kortum \& Lerner, 2000; Schwartz \& Bar-El, 2006). Three significant drawbacks exist related to hightech investing in the IVC industry in Israel. One drawback is the narrowing of geographical distribution of high-tech to the center of the country comprising metropolitan Tel Aviv (Schwartz, 2006; Schwartz \& Bar-El, 2006). The second drawback is restriction of technological diversification such as renewable energy sources (Avnimelech et al., 2007; Lerner, 2002). The third drawback is the small size of the Israeli domestic market as a constraint on sources of funding for venture capital (Baygan, 2003).

Israel needs to sustain growth in venture capital while reducing dependence on a limited number of capital sources (Baygan, 2003). Venture capital funds are generally formed as one or more limited partnerships investing in 
parallel (Levenfeld et al., 2009). The partnerships are generally registered in the Cayman Islands (for non-Israeli investors) and in Israel (for Israeli investors) for tax purposes (Levenfeld et al., 2009). Other jurisdictions where partnerships are sometimes formed are the British Virgin Islands and the Bailiwick of Jersey (Levenfeld et al., 2009). To a far lesser extent, funds can be organized as limited liability companies (LLCs) or as publicly traded companies (Levenfeld et al., 2009).

Venture capital funds in Israel typically raise the majority of funding from institutional investors in North America, Europe, and East Asia, especially Japan and Singapore (Levenfeld et al., 2009). Investors outside of Israel include pension funds, insurance companies, endowment funds, corporate or strategic investors, and high net-worth individuals (Levenfeld et al., 2009). Israeli pension funds, insurance companies, public funds via the Tel Aviv Stock Exchange, and banks invest in venture capital funds, but constitute a small portion of the overall funds raised (Levenfeld et al., 2009).

Venture capital industry is not regulated in Israel (Levenfeld et al., 2009). As venture capital funds are generally limited partnerships, the marketing and sale of interests in the partnerships is subject to applicable securities legislation (Levenfeld et al., 2009). The securities legislation in Israel restricts the offering of limited partnership units to no more than 35 persons, excluding certain qualified investors consisting primarily of financial institutions (Levenfeld et al., 2009). There is no exemption for high net-worth individuals (Levenfeld et al., 2009).

The most common investment objective of venture capital funds is to achieve long-term capital appreciation through the investment in, and exit via mergers, acquisitions, and initial public offerings of high growth, innovative technology companies (Blum, 2014). Venture capital funds generally have a seven-to-ten-year term with the ability to extend the term (Blum, 2014; Levenfeld et al., 2009). Venture capital funds usually strive to complete their investment period in three to four years of the fund's initial closing and to exit most of its investments within three to five years of investment (Levenfeld et al., 2009).

\section{STUDY PARAMETERS}

I contacted 150 venture capital directors and partners in the Israel during October and November 2014. From 150 directors and partners, 15 partners and directors from 15 venture capital firms agreed to be interviewed. The purposive sampling was representative of IVCs in Israel. Purposive sampling was appropriate because IVCs are a specialized group of participants who possess experiences and specific knowledge to address the research question (Parlalis, 2011). Participant selection was based on three criteria: (a) partner or director level IVC with an Israeli based firm, (b) was available to be contacted via telephone, and (c) was over the age of 18. The research question guiding the study what are the factors for the small number of renewable energy firms receiving funding in Israel?

Mason (2010) asserted that 15 participants was the smallest acceptable sample for a qualitative study. Hanson, Balmer, and Giardino (2011) confirmed that 10 to 20 participants were sufficient to confirm themes. Orser, Elliott, and Leck (2011) conducted a qualitative study with 15 interviewees. Participants were derived from venture capital firm websites. Websites were located from online searches of directories of IVC firms domiciled in Israel.

I e-mailed an introduction letter to potential interviewees asking whether the participant was interested in participating in the study. Each participant was a partner or director in the IVC firm. Participants were offered a gift card as remuneration for participating in the study. All interviews were conducted on the telephone. Cachia and Millward (2011) argued that utilizing the telephone for qualitative data collection was a viable option. The participants in the study responded to semistructured focused interviews asked in a conversational manner over the telephone (Yin, 2009). I utilized semistructured interviews to recognize broad themes and to direct the topic conversation in a systematic and consistent manner designed to elicit elaborate responses from participants (Qu \& Dumay, 2011). Interview questions used in the study were:

- What are the factors for the small number of renewable energy firms receiving funding in Israel?

- What renewable energy solutions would you consider investing in?

- How would investing in renewable energy solutions help Israeli's national security? 


\section{ISRAELI VENTURE CAPITAL INVESTMENTS IN RENEWABLE ENERGY}

In 2014, 6\% of IVC firms in Israel invested in renewable energy companies (Israel Science and Technology, 2014). Low numbers of IVC participation in renewable energy portfolio companies might be a result of poor return on investment, regulatory uncertainty, and lack of expertise. The first factor explores lack of high return on investment.

\section{Three Factors Contributing to Low Level of Funding Renewable Energy Firms}

The first factor cited by participants was the lack of high return on investment. Most participants argued high economic uncertainties exist prohibiting the investment in renewable energy firms. Another participant mentioned IVCs invest in disruptive technologies rather than a commodity such as electricity. Participants were also concerned about the changing market price of energy and technology innovation costs. Most participants mentioned the cost of producing renewable energy is prohibitive vis-a-vis fossil fuels. Participants mentioned entering into the renewable fuel market has high costs and low expected return on investment. Two participants argued the illiquidity of the investment is a limiting factor. For some IVCs, Israel's energy policy, regulatory environment, and investment practices and goals were noteworthy considerations and contribute to less than expected return on investment.

The second factor mentioned was the uncertainty of regulatory changes from the Israeli government. Because investments extend for three or more years, the risk was perceived as too high considering government regulation could reduce the value of a portfolio firm quickly. Participants mentioned that an electricity monopoly exists in Israel in the form of the state owned Israel Electric Company (IEC). IVCs mentioned Electricity Law 57561996, which regulates the electricity sector in Israel. IEC is required by regulation to provide electricity that is availability, has quality, efficiency, reliability, and be distributed throughout the country. The Law sets forth conditions for cost minimization and competition. Unless the electric company agrees buy energy generated from renewable energy firms, investment in renewable energy is mute. Participants argued an intransigent bureaucracy, a quixotic regulatory environment, and lack of available cost effective R\&D add to regulatory uncertainty. Although Israel has several renewable energy technology companies, the renewable energy focus on European and North American markets, not Israel. Participants cited the BIRD foundation as an example.

The third factor mentioned was most IVCs lacked knowledge and expertise of renewable energy technologies. IVCs mentioned the asymmetry of information would be too high. Although many IVCs acknowledged issues related to climate change, national security, and Israel's long history with solar energy, the expertise and knowledge to conduct a thorough due diligence was lacking.

\section{CONCLUSION}

Although the Israeli IVC industry is the fifth largest in the world, only $6 \%$ of Israel venture capital firms invest in renewable energy companies. I provided an overview of the State of Israel, Israeli energy policy, renewable energy, Israeli renewable energy policy, renewable energy use in Israel, and Israeli venture capital. I explained three factors for the small number of renewable energy firms receiving IVC funding in Israel.

\section{AUTHOR INFORMATION}

David Blum is an adjunct faculty mentor in the School of Business Management and Technology at Northcentral University. Dr. Blum holds a Bachelor's Degree in History from Bellarmine University, a Master of Business Administration (MBA) in Sustainable Business from Marylhurst University, and a Doctor of Business Administration (DBA) from Walden University. Dr. Blum lives in Haifa Israel. Email: davidblum2010@gmail.com 


\section{REFERENCES}

Ahituv, N. (2012). Israel's unfulfilled promise of alternative energy. Retrieved from http://www.haaretz.com/weekend/magazine/israel-s-unfulfilled-promise-of-alternative-energy-1.464910

Aguirre, A., \& Ibikunle, G. (2014). Determinants of renewable energy growth: A global sample analysis. Energy Policy, 69, 374-384. doi: 10.1016/j.enpol.2014.02.036

Avnimelech, G., Schwartz, D., \& Bar-El, R. (2007). Entrepreneurial high-tech cluster development: Israel's experience with venture capital and technological incubators. European Planning Studies, 15, 1181-1198. doi:10.1080/09654310701529078

Avnimelech, G., \& Teubal, M. (2008). From direct support of business sector R\&D/innovation to targeting venture capital/private equity: A catching up innovation and technology policy life cycle perspective. Economics of Innovation and New Technology 17, 153-172. doi:10.1080/10438590701279417

Bahgat, G. (2005). Energy partnership: Israel and the Persian Gulf. Energy Policy, 33, 671-677. doi:10.1016/j.enpol.2003.09.012

Baygan, G. (2003). Venture capital policy review: Israel. Retrieved from http://www.oecd.org/israel/2491258.pdf

Bloomberg. (2014). Global trends in renewable energy investment in 2014. Retrieved from http://fs-unepcentre.org/publications/gtr-2014

Blum, D. A. (2014). Venture capital best practice strategies to reduce economic uncertainty in biofuel investing. Journal of International Energy Policy, 3(1), 25-30. Retrieved from http://www.cluteinstitute.com/journalof-international-energy-policy-jiep/

Cachia, M., \& Millward, L. (2011). The telephone medium and semistructured interviews: A complementary fit. Qualitative Research in Organizations and Management: An International Journal, 6, 265-277. doi:10.1108/17465641111188420

Carley, S. (2009). State renewable energy electricity policies: An empirical evaluation of effectiveness. Energy Policy, 37, 3071-3081. doi:10.1016/j.enpol.2009.03.062

Central Bureau of Statistics. (2014). $66^{\text {th }}$ Independence Day -8.2 million residents in the State of Israel. Retrieved from http://www1.cbs.gov.il/reader/newhodaot/hodaa_template.html?hodaa=201411111

CIA World Factbook. (2014). Israel. Retrieved from https://www.cia.gov/library/publications/the-worldfactbook/geos/is.html

Escribano. G. (2008). Energy security and prospects for EU-Israel co-operation. Retrieved from $\mathrm{http} / / / \mathrm{www}$.iepn.org/index.php?option=com_content\&view=article\&id=7\&Itemid=10

EIA. (2013). Overview of oil and natural gas in the Eastern Mediterranean region. Retrieved from http://www.eia.gov/countries/analysisbriefs/Eastern_Mediterranean/eastern-mediterranean.pdf

EPA. (2014). Green power market. Retrieved from http://www.epa.gov/greenpower/gpmarket/

Florida, R. \& Kenney, M. (1988) Venture capital-financing innovation and technological change in the US. Research Policy, 17, 119-137. doi:10.1016/0048-7333(88)90038-8

Gompers, P. \& Lerner, J. (1999). The venture capital cycle. Cambridge, MA: The MIT Press.

Gompers, P. \& Lerner, J. (2001). The venture capital revolution, Journal of Economic Perspectives, 15, 145-168. doi:10.1257/jep.15.2.145

Hanson, J. L., Balmer, D. F., \& Giardino, A. P. (2011). Qualitative research methods for medical educators. Academic Pediatrics, 11, 375-386. doi:10.1016/j.acap.2011.05.001

He, Y., Wang, L., \& Wang, J. (2012). Cap-and-trade vs. carbon taxes: A quantitative comparison from a generation expansion planning perspective. Computers \& Industrial Engineering, 63, 708-716. doi:10.1016/j.cie.2011.10.005

Israel 21c. (2013). Did you know? Retrieved from http://www.israel21c.org/did-you-know-israel-facts/

Israel Science and Technology. (2014). Companies: Venture capital funds for Israeli startup companies. http://www.science.co.il/Venture-Capital-Funds.asp

Invest in Israel. (2014). Why Israel? http://www.investinisrael.gov.i1/NR/exeres/C901DB9C-83EE-4937-8CAD78D15B92A55B.htm

Karakosta, C., Doukas, H., \& Psarras, J (2010). EU-MENA energy technology transfer under the CDM: Israel as a frontrunner. Energy Policy, 38, 2455-2462. doi:10.1016/j.enpol.2009.12.039

Kortum, S. \& Lerner, J. (2000) Assessing the contribution of venture capital to innovation. RAND Journal of Economics, 31, 674-692. Retrieved from http://www.rje.org/ 
Lerner, J. (2002). When bureaucrats meet entrepreneurs: The design of effective 'public venture capital' program. The Economic Journal, 112, 73-84. doi:10.1111/1468-0297.00684

Levenfeld, B., Platt, B., Romem, Y., \& Arnon, Y. (2009). Venture Capital in Israel. Retrieved from http://www.arnon.co.il/files/e3b84790d602b8d3179de6a92b2be89a/25.\%20Venture\%20Capital\%20in\%20I srael\%20.pdf

Mason, M. (2010). Sample size and saturation in $\mathrm{PhD}$ studies using qualitative interviews. Forum: Qualitative Social Research, 11(3), 1-19. Retrieved from http://www.qualitative-research.net/index.php/fqs

Ministry of Economy. (2014). Israel's renewable energy sector. Retrieved from http://israelnewtech.gov.il/English/Energy/Pages/aboutus.aspx

Ministry of Environmental Protection. (2014). Renewable energy implementation in Israel: Facts \& figures. Retrieved from http:/www.sviva.gov.il/English/env_topics/energy/renewables/Pages/Renewable-EnergyImplementation-in-Israel.aspx

Ministry of Foreign Affairs. (2013a). Facts about Israel: The state. Retrieved from http://www.mfa.gov.il/mfa/aboutisrael/state/pages/the\%20state.aspx

Ministry of Foreign Affairs. (2013b). The land: Geography and climate. Retrieved from http://www.mfa.gov.il/mfa/aboutisrael/land/pages/the\%20land-\%20geography\%20and\%20climate.aspx

Ministry of National Infrastructures, Energy, \& Water Resources. (2014). Renewable energy sources. Retrieved from http:/energy.gov.il/English/Subjects/RenewableEnergy/Pages/GxmsMniRenewableEnergyAbout.aspx

Nasdaq. (2014a). Companies in Israel. Retrieved from http://www.nasdaq.com/screening/companies-byregion.aspx?region=Middle+East\&country=Israel

Nasdaq. (2014b). NASDAQ companies. Retrieved from http://www.nasdaq.com/screening/companies-byindustry.aspx? exchange $=$ NASDAQ $\&$ page $=60$

NREL. (2014). Concentrating solar power projects. Retrieved from http://www.nrel.gov/csp/solarpaces/project_detail.cfm/projectID=277

OECD. (2011). Policies to support eco-innovation in Israel. Retrieved from http://www.oecd.org/israel/48354947.pdf

Orser, B. J., Elliott, C., \& Leck, J. (2011). Feminist attributes and entrepreneurial identity. Gender in Management: An International Journal, 26, 561-589. doi:10.1108/17542411111183884

Pearce, B. (2014). Adapting and evolving: Global venture capital insights and trends 2014. Retrieved from http://www.ey.com/Publication/vwLUAssets/Global_venture_capital_insights_and_trends_2014/\$FILE/EY Global_VC_insights_and_trends_report_2014.pdf

Parlalis, $\bar{S}$. K. (2011). Management of organisational changes in a case of de-institutionalisation. Journal of Health Organization and Management, 25, 355-384. doi:10.1108/14777261111155010

Qu, S. Q., \& Dumay, J. (2011). The qualitative research interview. Qualitative Research in Accounting \& Management, 8, 238-264. doi:10.1108/11766091111162070

Schwartz, D. (2006). The regional location of knowledge-based economy activities in Israel. Journal of Technology Transfer, 31, 31-44. doi:10.1007/s10961-005-5011-9

Schwartz, D. \& Bar-El, R. (2007). Venture investments in Israel - A regional perspective. European Planning Studies, 15, 623-644. doi:10.1080/09654310701213905

Sjöö, K. (2008). The influence of uncertainty on venture capital investments in renewable energy technology: An exploratory study. Retrieved from https:/www.duo.uio.no/handle/10852/17873

U.S. Department of Energy. (2012). 2012 renewable energy data book. Retrieved from http://www.nrel.gov/docs/fy14osti/60197.pdf 


\section{NOTES}

